\title{
M. Blanco, Edipo non deve nascere. Lettura delle "Poésies" di Mallarmé
}

\section{Andrea Schellino}

\section{(2) OpenEdition}

1 Journals

\section{Édition électronique}

URL : http://journals.openedition.org/studifrancesi/10025

DOI : 10.4000/studifrancesi. 10025

ISSN : 2421-5856

Éditeur

Rosenberg \& Sellier

\section{Édition imprimée}

Date de publication : 1 août 2017

Pagination : 388

ISSN : 0039-2944

\section{Référence électronique}

Andrea Schellino, "M. Blanco, Edipo non deve nascere. Lettura delle "Poésies" di Mallarmé ", Studi Francesi [En ligne], 182 (LXI | II) | 2017, mis en ligne le 01 août 2017, consulté le 09 janvier 2021. URL http://journals.openedition.org/studifrancesi/10025; DOI : https://doi.org/10.4000/studifrancesi. 10025

Ce document a été généré automatiquement le 9 janvier 2021.

\section{(c)}

Studi Francesi è distribuita con Licenza Creative Commons Attribuzione - Non commerciale - Non opere derivate 4.0 Internazionale. 
M. Blanco, Edipo non deve nascere. Lettura delle "Poésies" di Mallarmé

Andrea Schellino 


\section{RÉFÉRENCE}

MASSIMO BLANCO, Edipo non deve nascere. Lettura delle "Poésies" di Mallarmé, Firenze, Leo S.

Olschki, 2016, «Biblioteca dell“"Archivum romanicum”», 246 pp.

1 Ricercatore à l'Università La Sapienza de Rome, spécialiste de la poésie française de la seconde moitié du $\mathrm{XIX}^{\mathrm{e}}$ siècle et de la première moitié du $\mathrm{Xx}^{\mathrm{e}}$ siècle, Massimo BLANCo consacre son dernier livre aux Poésies de Mallarmé, dont il veut identifier les «chiavi ermeneutiche» (p. vII) permettant d'affronter ce corpus lyrique dans son unité. Il utilise pour cela le concept de «mythe solaire», en évitant cependant de séparer les «personnes» au sein de la mythologie - telles qu'ÆEdipe, Jocaste ou Orphée - des composantes abstraites ou idéologiques du mythe. Pour Massimo Blanco, les figures divines ou mythiques peuplant la poésie de Mallarmé sont les intermédiaires des absents, des disparus: sa mère, sa sœur, Anatole... L'Auteur va ainsi à l'encontre des thèses de Gardner Davies, coupable à ses yeux de dépersonnaliser excessivement le «drame solaire» - mais aussi de celles de Bertrand Marchal. Selon Massimo Blanco, la «visione di Marchal rischia di trascurare talune ragioni personali del poeta. In tale prospettiva Mallarmé sembra una sorta di Cartesio preoccupato della visione umana del mondo in rapporto a delle verità possibili e assai meno come un individuo dotato di sentimenti, di una propria affettività» (p. IX). Ainsi conçu, l'athéisme de Mallarmé aurait un caractère comtien (voir ibid.).

2 À ces approches, l'Auteur oppose une méthode critique vouée à faire émerger un tissu référentiel et personnel. Dans la première partie de son ouvrage, ayant fonction d'introduction, il se penche sur deux projets de Mallarmé: le Livre et le dossier du Faune. La seconde partie contient une étude, poème par poème, des Poésies, avec une concise mais utile bibliographie analytique et critique. 